\title{
An Analysis of the Incomes and Current Personal Transfers of Hungarians Living Abroad*
}

\author{
Orsolya Csortos - Balázs Kóczián
}

The funds transferred or available for transfer home by households working abroad appear in several items of the balance of payments, which often leads to misunderstandings. This paper therefore attempts to define these concepts. It is necessary to clarify and understand the concepts associated with remittances because they may represent more stable sources of external funding compared to other external sources, and may also shape economic growth, improve the current account and thus contribute to reducing the risk premium and improving investor sentiment on the country. After illustrating the economic significance of the compensation of employees and transfers, we shed light on their trends in recent years in Hungary. The United Kingdom's referendum on EU membership in June 2016 lends particular relevance to the topic. We show that the compensation of employees working temporarily abroad significantly exceeds the current personal transfers of Hungarian households permanently living abroad, and these significantly improve the current account. Hungarian workers in Germany and Austria received the majority of wages, while the United Kingdom also plays a prominent role alongside Germany in current personal transfers made by Hungarian households living permanently abroad. At the scale of the European Union, the volume of compensation of employees and current personal transfers decreases in parallel with the level of economic development.

Journal of Economic Literature (JEL) codes: F24, E01, F43, J61

Keywords: remittances, foreign worker incomes, external funding, labour flow

\footnotetext{
* The views expressed in this paper are those of the author(s) and do not necessarily reflect the offical view of the Magyar Nemzeti Bank.

Orsolya Csortos is an Economist at the Magyar Nemzeti Bank.E-mail: csortoso@mnb.hu. Balázs Kóczián is an Economist at the Magyar Nemzeti Bank. E-mail: koczianb@mnb.hu.

The views expressed in this article are those of the authors and do not necessarily reflect the official view of the Magyar Nemzeti Bank. The authors would like to thank the staff of the Magyar Nemzeti Bank's Macro Finance and External Balance Department for their input for this research and the anonymous editors for their constructive comments.

The manuscript was received on 9 December 2016.
}

DOI: http://doi.org/10.25201/FER.16.2.527 


\section{Introduction}

After Hungary joined the European Union, the number of Hungarian citizens working abroad started rising as workers took advantage of the free movement of labour and differences in wage levels. As the number of Hungarians working abroad has increased, the value of compensation of employees and current personal transfers has also risen. Although papers on the significance of working abroad (Bodnár Szabó 2014) and on the volume of worker remittances (Kajdi 2015) have already been published, trends in the foreign compensation of employees and current transfers in recent years have not been represented in a breakdown by country or analysed in depth. The outcome of the United Kingdom's referendum on European Union membership held in June 2016 is what primarily shed light on the significance of the matter from a Hungarian perspective.

In the second chapter of our paper, we define the concepts linked to remittances and present the available data and constraints on obtaining data. Chapter 3 provides an overview of the potential economic impacts of the compensation of employees and transfers based on the literature. Chapter 4 gives an in-depth analysis of trends in the compensation of employees and the current personal transfers of Hungarians working abroad. Chapter 5 places Hungarian trends in an international context, while Chapter 6 sums up the main findings of the study.

\section{Defining the concepts related to remittances}

The funds transferred or available for transfer home by workers living and working abroad appear in several items of the balance of payments, and thus the following chapter attempts to clarify these concepts. However, before we give an overview of where the funds received from households working abroad appear in the balance of payments statistics, it should be noted that the balance of payments shows transactions between resident and non-resident households. In the balance of payments, residence is not primarily defined based on the economic agent's citizenship, but on where its "fundamental economic interests" are tied to (MNB 2014). In other words, a Hungarian citizen can be a resident in either Hungary or Germany. To put it simply, an economic agent is a resident in the country where he or she lives habitually, over the long term. Residing abroad for more than one year is generally regarded as long term, with a few exceptions such as exchange students and diplomats (IMF 2009). The following section presents a structured classification of the indicators that exist in relation to remittances, first presenting the two indicators that can be directly observed in the balance of payments. 


\section{(1) Compensation of employees temporarily working abroad}

Compensation of employees is recognised among primary incomes in the balance of payments and shows the amount of gross labour income earned by workers temporarily living abroad (working abroad for less than one year). As the balance of payments records transactions between resident and non-resident agents, which is the wage paid to the Hungarian worker by a foreign employer in case of short-term work abroad, the balance of payments shows the gross wage. As a result, this time series shows the amount of wages received from non-resident economic agents instead of the amount of money transferred home by resident agents. As workers then pay taxes on these wages in the country in question ${ }^{1}$ and spend a portion of their income on the cost of living, which is difficult to quantify, presumably only a portion of employees' income is actually transferred home. For this reason, it would be misleading to call this indicator a remittance, as only a portion of it can be transferred home.

\section{(2) Current personal transfers of households permanently living abroad}

The secondary incomes of the current account show the amount of money transferred home to domestic households by households living permanently abroad. When a household moves abroad for the long term (for more than one year) and its economic interest shifts to the new country, it becomes a non-resident agent and from this point on, the transaction of receiving wages from its non-resident employer is no longer included in the original home country's balance of payments data (as the transaction takes place between two non-resident agents). At the same time, as a household living abroad is now a non-resident agent, transfers by this household to a household in Hungary give rise to a transaction between a resident and a non-resident agent, which is thus recognised among the secondary incomes in the balance of payments (called current transfers in the earlier balance of payments methodology). This item of the balance of payments also contains other items that are addressed in-depth later in this study.

It is therefore apparent that several items of the current account contain elements that workers living abroad could transfer home; however, in our view, neither one of these nor their sum should be referred to as remittances. In order to understand and analyse the amount of money that domestic households working abroad may be transferring home, new concepts should be defined. Using precise terminology is rendered difficult by the diverging use of terminology in international statistics and the fact that the international literature often fails to clarify the above concepts. Amongst others, the World Bank refers to the sum of concepts (1) and (2) as personal remittances. By contrast, the terminology used by Eurostat offers a more accurate description of the concept used by the institution for its analyses

\footnotetext{
${ }^{1}$ This is recognised among the secondary incomes of the current account.
} 
("workers' remittances and compensation of employees"), which also refer to the sum of items (1) and (2). Besides these international organisations, numerous other domestic and international authors proceed similarly, so this concept also calls for definition. Figure 1 illustrates the relations between concepts related to remittances.

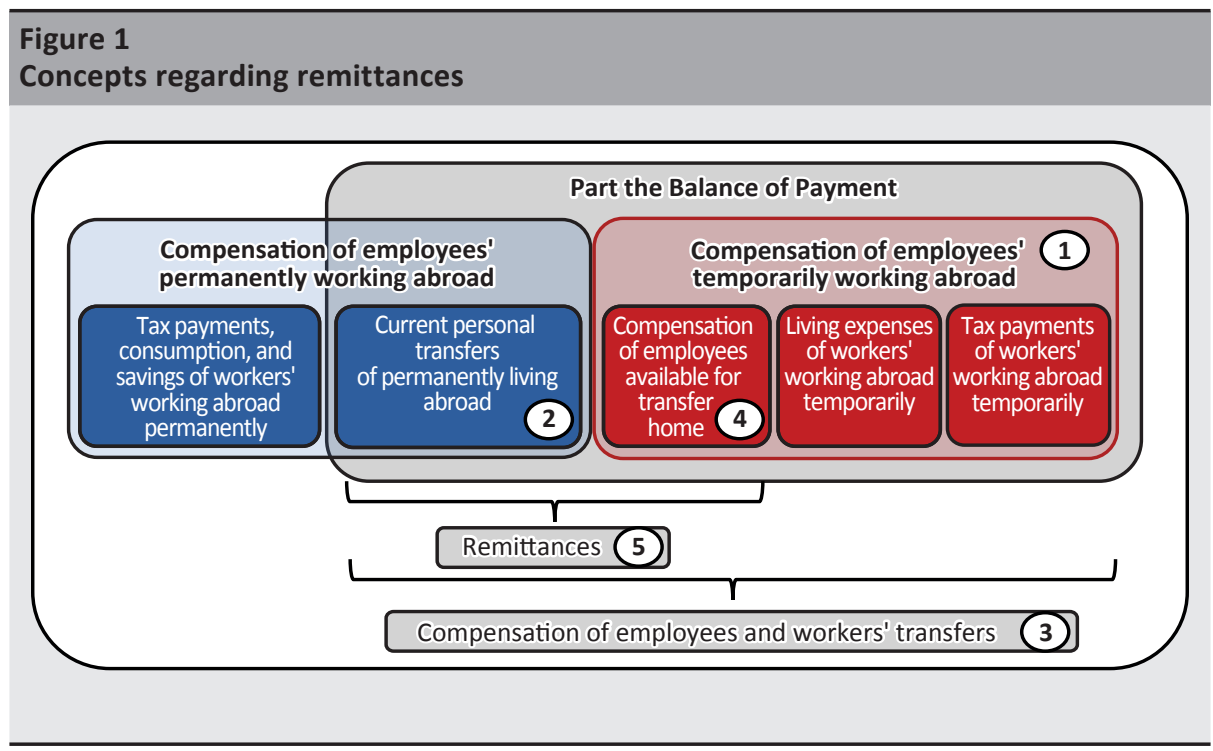

\section{(3) Compensation of employees and workers' transfers}

According to our definition, similarly to Eurostat and the World Bank, this item contains the compensation of employees temporarily working abroad and transfers of workers permanently living abroad [(1)+(2)]. However, this item contains the tax burden on the compensation of employees and the portion of income used to cover the cost of living, in other words the sum of (1)+(2) is not transferred home in full. As a result, referring to the sum of items (1) and (2) as remittances would be inaccurate in spite of the fact that this is the terminology often used by the literature and the press.

\section{(4) Compensation of employees available for transfer home}

This concept refers to the value of compensation of employees (1) less taxes, social contributions, costs of living and consumption expenditures. However, quantifying these items is problematic ${ }^{2}$ for several reasons that go beyond the scope of this paper.

\footnotetext{
${ }^{2}$ Taxes and social contributions are recognised among the secondary incomes of the current account. Although data on the consumption expenditures abroad of domestic residents is available as it is considered a domestic service import, there is uncertainty within this category on the portion represented by consumption of shortterm migrant workers and by domestic tourists traveling abroad.
} 


\section{(5) Sum of current private transfers (2) and compensation of employees available for transfer home (4)}

In our opinion, this concept sums up all of the items that workers temporarily and permanently living abroad could transfer home, and thus for the sake of simplicity, we will refer to this concept in the rest of this paper as "remittances". According to our definition, remittances include transfers by households working abroad for the long term (working abroad for more than one year) and the portion of the compensation of employees working temporarily abroad (working abroad for less than one year) less taxes, which has not been spent on consumption. However, as highlighted in the previous section, because there is no accurate data on the latter item, the precise volume of remittances is difficult to quantify, which is particularly problematic because most analyses attempt to investigate the impacts of the contents of these remittances.

\section{Economic impacts of compensation of employees and transfers based on the literature}

This chapter presents the economic impacts of the compensation of employees and current transfers from several aspects. Here again, we would stress that most of the literature uses the term "remittances", possibly stemming from the fact that they attempt to analyse the impacts of remittances [(5)], which we have also described, that make the most sense economically. By contrast, as highlighted earlier, the term "remittances" most often refers to the sum of items (1) and (2), i.e. compensation of employees and current personal transfers [(3)]. For the sake of consistent terminology, we have no choice other than to use the cumbersome but accurate expression "compensation of employees and transfers" as the majority of the literature bases its analyses on World Bank data, which is consistent with this expression [(3)]. Although the concepts of remittances and compensation of employees and transfers are often used inaccurately in various analyses, their qualitative economic impacts (on income distribution, welfare, growth and the balance of payments) and broad trends are largely identical. The only significant differences can be found in the degree of impact on individual variables, as remittances form a subset of compensation of employees and current personal transfers.

According to the World Bank data, compensation of employees and current personal transfers as a percentage of GDP is typically the highest in the Asian and African countries, while Hungary's figure is considered moderate (but significant by regional standards) (Figure 2). According to the World Bank's data, compensation of employees and current personal transfers exceed 20-30 per cent of GDP in many Asian and African countries, so much of the literature tends to focus on developing, lower-income countries when analysing these transactions. Compensation of employees and current personal transfers as a percentage of GDP in Central and 
South-eastern Europe and the Baltic States amount to less than 10 per cent; compared to this, Hungary's figure of 3.3 per cent is moderate, but slightly exceeds the regional average for Central and Eastern Europe. With this in mind, this paper focuses mainly on the impacts of compensation of employees and current personal transfers in the economies of the region and less so on the impacts of migration and the trends exhibited in the poorest countries.

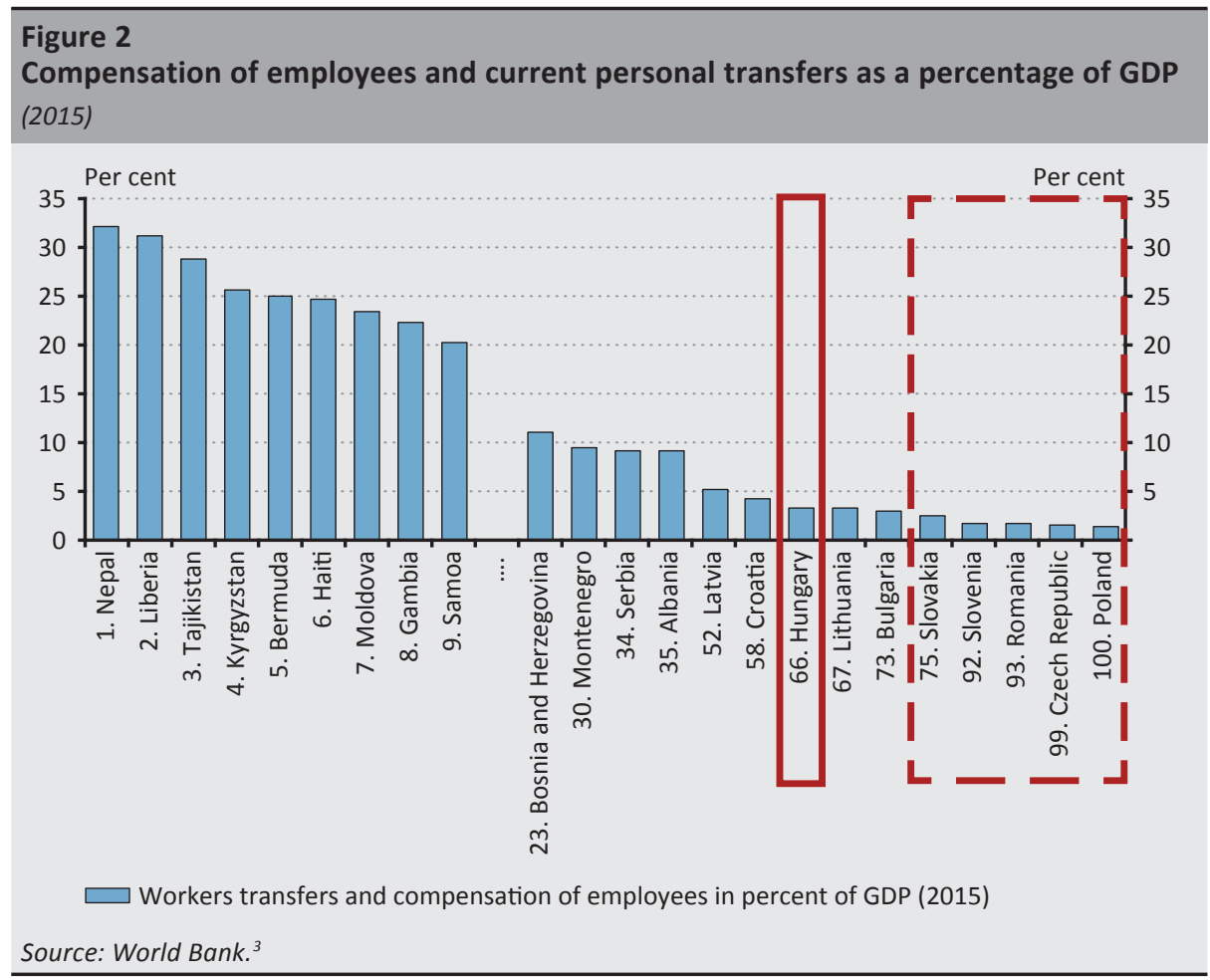

The impacts of compensation of employees and current personal transfers are typically classified in three groups by the literature (OECD 2006). The first topic is the impact of compensation of employees and current personal transfers on income distribution, poverty alleviation and individual welfare, the second topic is the impact on growth, employment and productivity, and the third topic is the impact on the balance of payments. That said, other classifications for analysing the impacts are also possible, such as the one used in a European Parliament analysis (European Parliament 2014) which distinguishes micro-level and macro-level impacts. As this paper relies on aggregate data, we essentially adhere to the OECD classification.

\footnotetext{
${ }^{3}$ http://www.worldbank.org/en/topic/migrationremittancesdiasporaissues/brief/migration-remittances-data.
} 


\subsection{Impacts on income distribution and welfare}

The impact of compensation of employees and current personal transfers on income distribution is unclear based on empirical studies, while it may alleviate the risks associated with poverty. They may either decrease (Ahlburg 1996; Taylor 1999) or increase the Gini coefficient that measures social inequality (Adams 1991). The impact on income distribution may be influenced by the stage of the migration wave that a country is currently experiencing. During the initial phase of migration, typically wealthier families may seek work abroad, which may increase inequalities (World Bank 2011; Stark et al. 1988). In later stages of migration, poorer groups may also seek work abroad to a greater extent, and thus their compensation and current personal transfers may also alleviate social inequalities in the longer run (Stark - Taylor - Yitzhaki 1988). Many empirical studies reveal a rise in consumption expenditures among households that are recipients of incoming transfers, which face lower chances of sinking into poverty compared to those which receive no funding from abroad (Ratha 2013). In addition, compensation of employees and current personal transfers shield households from external shocks and act as a form of social insurance in countries plagued by frequent political or economic turmoil (Kapur 2004).

Compensation of employees and current personal transfers may boost economic and household welfare by generating higher income available for education spending. Some studies point out that migration and compensation of employees and current personal transfers have a positive impact on the host country's human capital (de Haas 2007). It is also possible that the funds received following emigration do not compensate for the loss generated by the brain drain of highly skilled labour, but this exceeds the scope of our paper's objectives. The IMF (2016) study shows that in CESEE ${ }^{4}$ countries, the qualification and education of emigrants is significantly higher than the national average.

Several studies show that compensation of employees and current personal transfers may play a pronounced social role beyond their financial and economic significance. While the bulk of analyses focused on the monetary and financial impacts of inflowing funds, their non-financial and in-kind forms are just as significant. Levitt's (1998) paper shed light on the significance of the cultural and social impacts of migration. The "transfer" of non-financial and in-kind benefits may have a significant impact on social development through numerous areas such as education, healthcare, gender equality or the brain gain.

\footnotetext{
${ }^{4}$ Albania, Belarus, Bosnia and Herzegovina, Bulgaria, Croatia, Czech Republic, Estonia, Hungary, Kosovo, Latvia, Lithuania, Macedonia, Moldova, Montenegro, Poland, Romania, Russia, Serbia, Slovak Republic, Slovenia, Turkey, and Ukraine.
} 


\subsection{Growth impacts}

Compensation of employees and current personal transfers may stimulate economic growth through various channels. Numerous studies have shown that the continuous influx of compensation of employees and current personal transfers mitigates the volatility of output (IMF 2005; World Bank 2006; Chami et al. 2008), while several empirical analyses have shown that they have a positive impact on the host country's economic growth (Solimano 2003, World Bank 2006). That said, several authors stressed that the impact on growth depends on numerous factors (such as its absorption). Compensation of employees and transfers stimulate consumption and investment and may thereby mitigate the degree of recession and foster a pickup in the host country's economic growth. In addition, absorption by consumption or investment also has secondary or multiplier effects. Such multiplier effects include expanding retail sales, which boosts demand and ultimately, output and employment as well (Lowell - de la Garza 2000; Ratha 2003). Indirect impacts may also be generated by the fact that incoming compensation of employees and current personal transfers free up funds that can thus be used for investment, which has a positive impact on employment and growth. Léon-Ledesma-Piracha (2001) estimate that in 11 Central and Eastern European countries, compensation of employees and current personal transfers significantly increase the economy's funds available for investments.

That said, compensation of employees and current personal transfers may also have adverse impacts on growth. The impacts on employment, inflation and imports depend on the flexibility with which the supply side of the economy is able to react to higher demand in the wake of the compensation of employees and current personal transfers received. For instance, if supply is unable to adequately adjust to increased demand, it may result in inflationary effects (Adams 1991; Barajas et al. 2011; El-Sakka 1999). There is a high likelihood that the funding received is spent by the recipient households on consumption goods (generally imported goods), instead being used for domestic investments or savings. In line with this, several authors (Alper - Neyapti 2006; de Haas 2007) found that compensation of employees and current personal transfers may only foster investments and economic growth over the longer run. Meanwhile, the receipt of compensation of employees and current personal transfers and constant reliance on such may decrease labour market participation and the number of hours worked (Buch et al. 2002; Chami et al. 2003). Rising inactivity may also increase the wage level and the inflow of funds may lead to appreciation of the real exchange rate (Chami et al. 2008; Bourdet - Falck, 2006; Barajas et al. 2011). The IMF (2016) demonstrates that the influx of compensation of employees and current personal transfers significantly increases labour market inactivity by increasing reservation wages. In extreme cases, reliance on incoming funds may be a unique source of contagion: if the country 
sending the funds is affected by a crisis, the recipient countries will also feel an adverse effect (Alvarez-Tinajera 2010).

Compensation of employees and current personal transfers may have a positive impact on economic prospects through financial deepening. According to the IMF's (2016) calculations, in countries where reliance on compensation of employees and transfers is high (remittances exceed 10 per cent as a percentage of GDP), they may foster deepening of the financial system, which is generally measured through private sector credit and deposits as a percentage of GDP. The funds received may increase private sector bank deposits and thus the stock of extended credit, which may ultimately stimulate investments (Aggarwal et al. 2006; Giuliano and Ruiz-Arranz 2005, 2009; Gupta et al. 2009; Ratha 2013). Compensation of employees and current personal transfers received may enable the accumulation of financial and non-financial assets, which in turn improves access to financial services and investment opportunities (Orozco et al. 2005; IMF 2005). Yasseen (2012) demonstrates a positive correlation between compensation of employees and current personal transfers and the level of financial system development in emerging countries. That said, these positive impacts may wane as migration becomes permanent or increases.

In light of these findings, the link between compensation of employees and current personal transfers and economic growth is not clear, and the potential positive impacts are not a silver bullet in and of themselves and cannot replace adequate economic policy for any country (Stratan et al. 2013). The right economic policy and development strategies are best able to ensure that the compensation of employees and transfers received by developing countries exert a positive impact on growth. In addition, the adverse effects of emigration and reliance on compensation of employees and current personal transfers can be mitigated with economic policy measures that create an economic and institutional environment that does not promote additional emigration or supports the return of emigrants, that fosters greater labour market activity of those who remain in the country and supports the allocation of the funds received to investments rather than consumption (IMF 2016).

\subsection{Impact on the balance of payments}

Compensation of employees and current personal transfers have a positive impact on and foster the achievement of a sustainable current account over the long run. The fact that compensation of employees and current personal transfers have turned out to be a more stable source of funding and are less cyclical compared to other external funding (such as international aid, FDI or credit, see below for more details), has numerous positive consequences for the balance of payments and its sustainability (IMF 2005; Ratha et al. 2009). The advantage of compensation of employees and current personal transfers is that their utilisation is not tied to the use of high import-content investment projects, they do not have to be repaid 
and are not subject to any interest. Most research also emphasises that higher demand for imports is the result of economic development, structural changes in consumption and capital goods production or changes in international labour distribution (Glytsos 1993; Straubhaar 1988).

The stability of compensation of employees and current personal transfers contributes to the economic stability of the recipient country. Maintaining the current account at a level that does not jeopardise the sustainability of external debt is essential for open economies (Holmes 2006). Buch and Kuckulenz $(2010)^{5}$ showed that by positively impacting the current account, compensation of employees and current personal transfers decrease a country's risk premium and improve investor sentiment by reducing external debt; ultimately, these factors result in better financing conditions which fosters investment and economic growth. Hassan and Holmes (2015) showed that compensation of employees and current personal transfers result in less persistent shocks affecting the current account and quicker ensuing adjustment. Furthermore, Bugamelli and Paternò (2009) demonstrated that compensation of employees and current personal transfers decrease the likelihood of current account crises and thus the likelihood of financial crises. By contrast, certain studies point out that the funds received may push property prices up in the recipient country, which may lead to the misallocation of funds and pose a risk for financial stability (Stepanyan - Poghosyan - Bibolov 2010).

\section{Trends in the compensation of employees and current personal transfers in Hungary}

As we have demonstrated so far, compensation of employees and current personal transfers may have various macroeconomic impacts, and thus an indepth investigation of their trends in Hungary is warranted. As shown in Chapter 2 , referring to the sum of the two items as remittances would be misleading, as households working temporarily abroad can actually only transfer a portion of their gross wages back to Hungary, as the remainder is used to pay taxes and cover the cost of living. ${ }^{6}$ This chapter and paper do not attempt to give an estimate of the value of remittances by Hungarian working abroad, but instead strive to provide an overview of data included in the balance of payments, i.e. of the trends in Hungarian households working abroad temporarily [(1) in our list above] and transfers by Hungarian households working abroad over the longer term (2). The following chapter presents these items in-depth.

\footnotetext{
${ }^{5}$ Similarly, several empirical studies emphasise that remittances decrease the current account deficit (Buch et al. 2002; Buch - Kuckulenz 2004; Nayyar 1994).

${ }^{6}$ It should also be mentioned that these two items are also included in balance of payments data, as tax payments are recognised among transfers (for instance, the value of income spent abroad on consumption in the value of import) while the saved portion of income is reflected in the increase of financial assets.
} 


\subsection{Where are compensation of employees and transfers reported among data?}

Compensation of employees is included in the income balance (among primary incomes) and its balance has decreased the income balance deficit more and more in recent years. Gross compensation of employees (including taxes) is included in the income balance. The balance of this item (that is, the difference between the revenues and expenses) has decreased the income balance deficit by nearly 3 per cent of GDP in recent quarters and has increased the current account surplus (Figure 3). Nevertheless, the income balance deficit amounted to 5-6 per cent of GDP, as the profit of corporations in non-resident ownership and interest paid on foreign loans significantly exceeded this item.

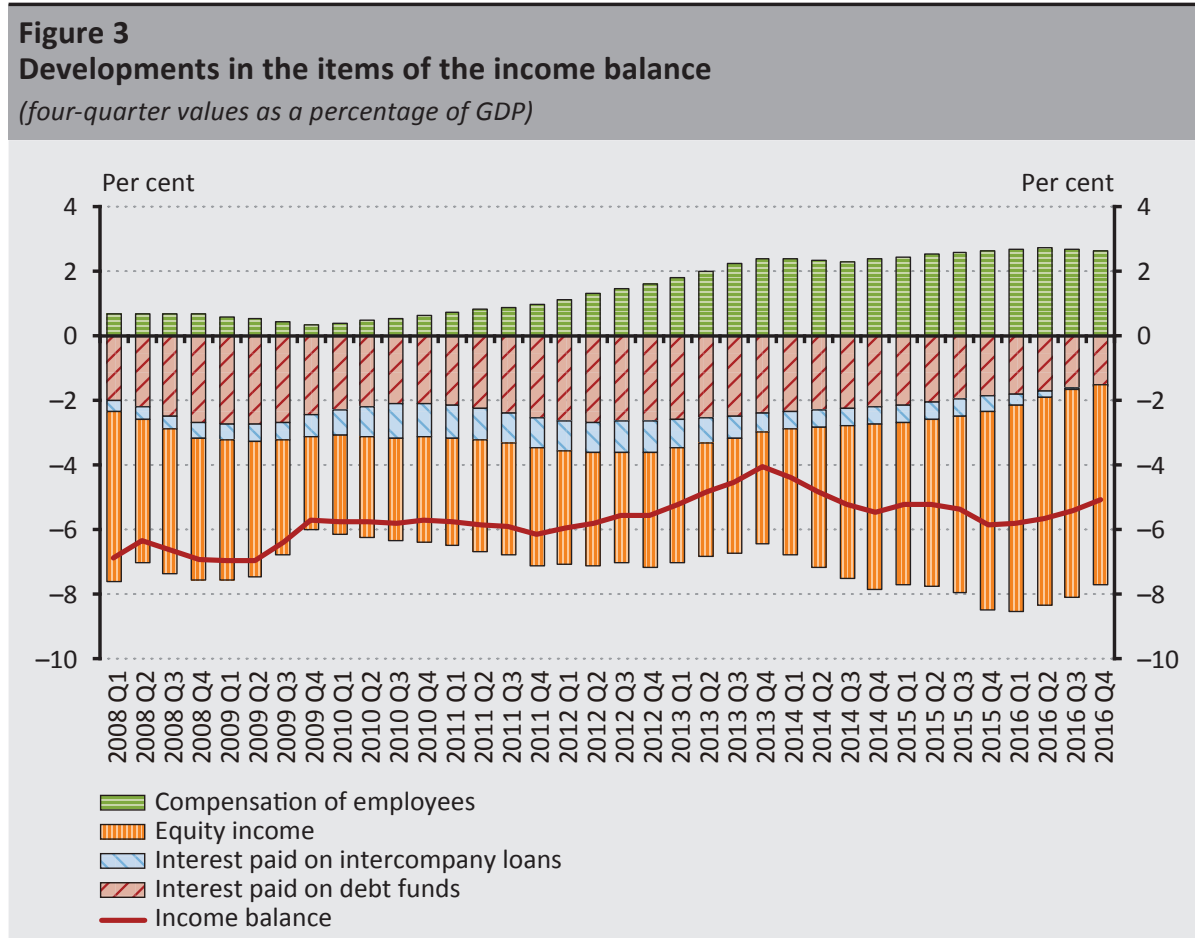

Source: MNB, HCSO.

Current transfers by households working permanently abroad are recognised among the secondary incomes of the current account. Households working permanently abroad are classified as non-resident for the reasons described earlier. Unrequited transfers by non-residents to domestic agents are recognised among other current and capital transfers, a subset of secondary incomes. Similarly to the MNB's analyses, we refer to these as the transfer balance along with other 
primary incomes and the items of the capital account (Figure 4). That said, other current transfers also include other items such as taxes on wages paid to the host country of households working temporarily abroad. Therefore, the fact that the balance of other current transfers besides EU transfers broadly exhibits net payment means that taxes paid by households working temporarily abroad exceed current private transfers by households living permanently abroad. That said, current private transfers by households working permanently abroad can be studied based on other data reporting entities (such as Eurostat, which publishes data supplied to national statistical bodies). Based on this, their value in recent years was around 0.5 per cent of GDP, which fell far short of the wages of households working temporarily abroad. In terms of trends in the transfer balance surplus, the absorption of EU transfers is a dominant factor.

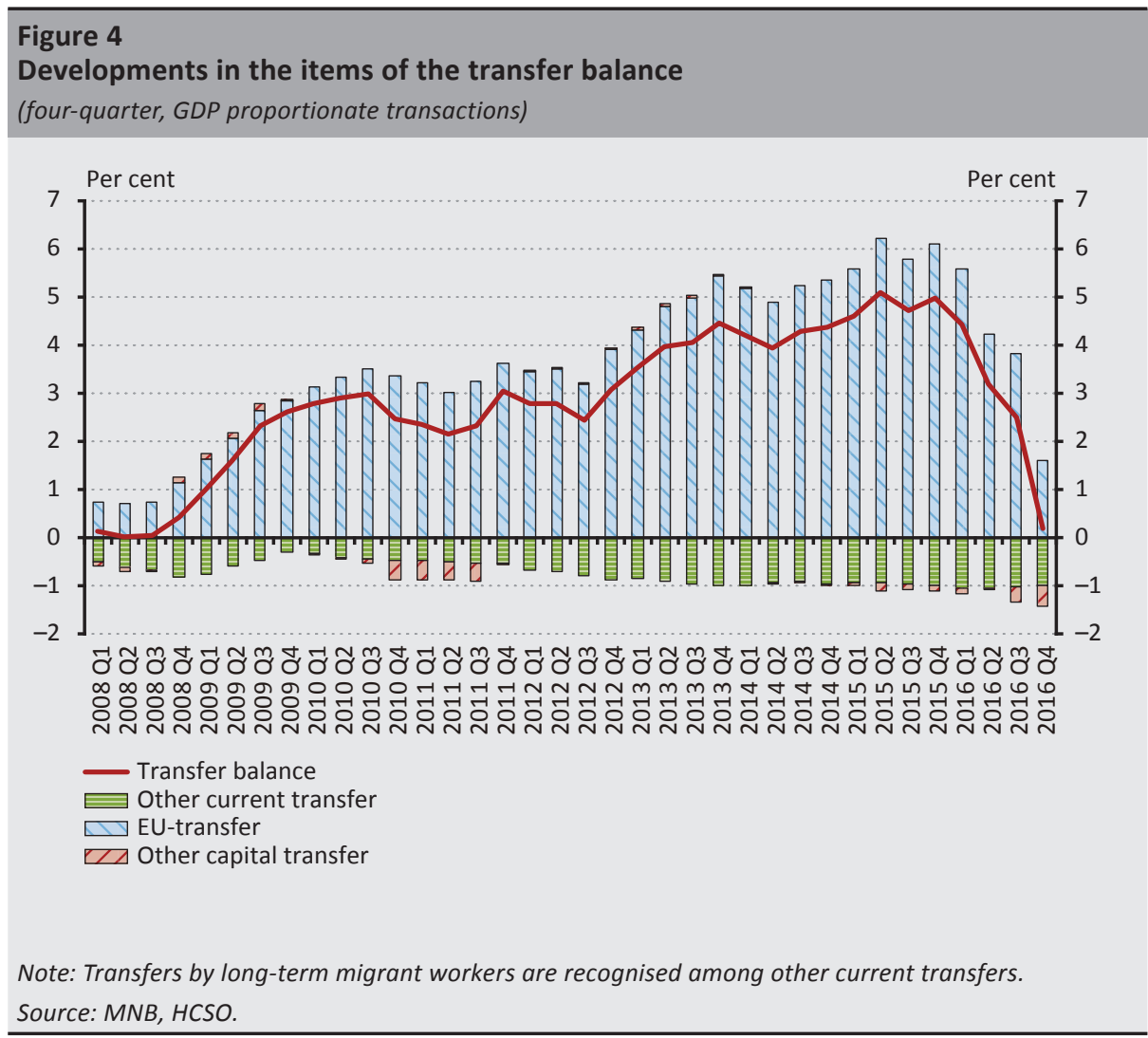

It is worth noting that while so far we have relied on data from the balance of payments, the following part of our paper presents the data on compensation of employees and current private transfers published by Eurostat (among balance of payments data), in the context of which we provide an overview of transfers of 
households working permanently abroad alongside compensation of employees, which partly contain actual remittances. Eurostat allows for an in-depth analysis of data on the compensation of employees and transfers in a breakdown by country.

\subsection{Compensation of employees by households working temporarily abroad}

Compensation of employees decreased following the crisis, in part due to rising unemployment, but has increased gradually as growth stabilised and the last restrictions on work within the European Union were lifted. Compensation from temporary work abroad amounted to around EUR 1.2-1.5 billion prior to the crisis, before dipping significantly in 2009. The fact that the crisis affected neighbouring countries and that rising unemployment presumably affected migrant workers to a greater extent (which confirms the hypothesis presented in the chapter on theory whereby remittances may also be a channel of contagion) may have played a pivotal role in this. At the same time, the influx of external funds in Hungary (meaning the influx of debt liabilities and net FDI) contracted to a far greater degree after the crisis because - as mentioned in the chapter on theory - foreign wages decreased to a smaller extent, in other words they were a source of more stable funding for economic agents. Compensation of employees subsequently started climbing gradually and amounted to nearly EUR 3 billion by 2013; however, as explained earlier, only a portion of these wages is actually available for remittance. The increase began in earnest after 2010 and was felt in Germany to the greatest degree, as shown by the data broken down by country. The fact that Germany's last restrictions affecting Hungarian workers were lifted in early 2011 also played a significant role in this. Factoring in the wages of households working temporarily working in Hungary, compensation of employees contributed EUR 2.5-3 billion to the current account between 2013 and 2016, which also contains taxes and the cost of living.

Germany and Austria are the main destinations for Hungarian workers seeking temporary work abroad (Figure 5). Temporary work abroad typically includes seasonal and border worker. Taking this, plus the differences in wage levels among countries into account, it comes as no surprise that the vast majority of foreign wages come from temporary work abroad in Austria followed by Germany, which is located farther from Hungary but is still at an accessible distance and is easily accessible. This coincides with the data derived from the labour force survey published in the Statisztikai Szemle (Lakatos 2015). Approximately three quarters of the nearly EUR 3.5 billion in total compensation of employees came from these two countries in 2016. It is also worth noting that the wages of short-term (non-resident) workers in Hungary amounted to nearly EUR 500 million. Workers temporary living in Hungary generally came from neighbouring countries, mainly from Romania and Slovakia. This is presumably due to workers living in these countries whose native language is Hungarian. 


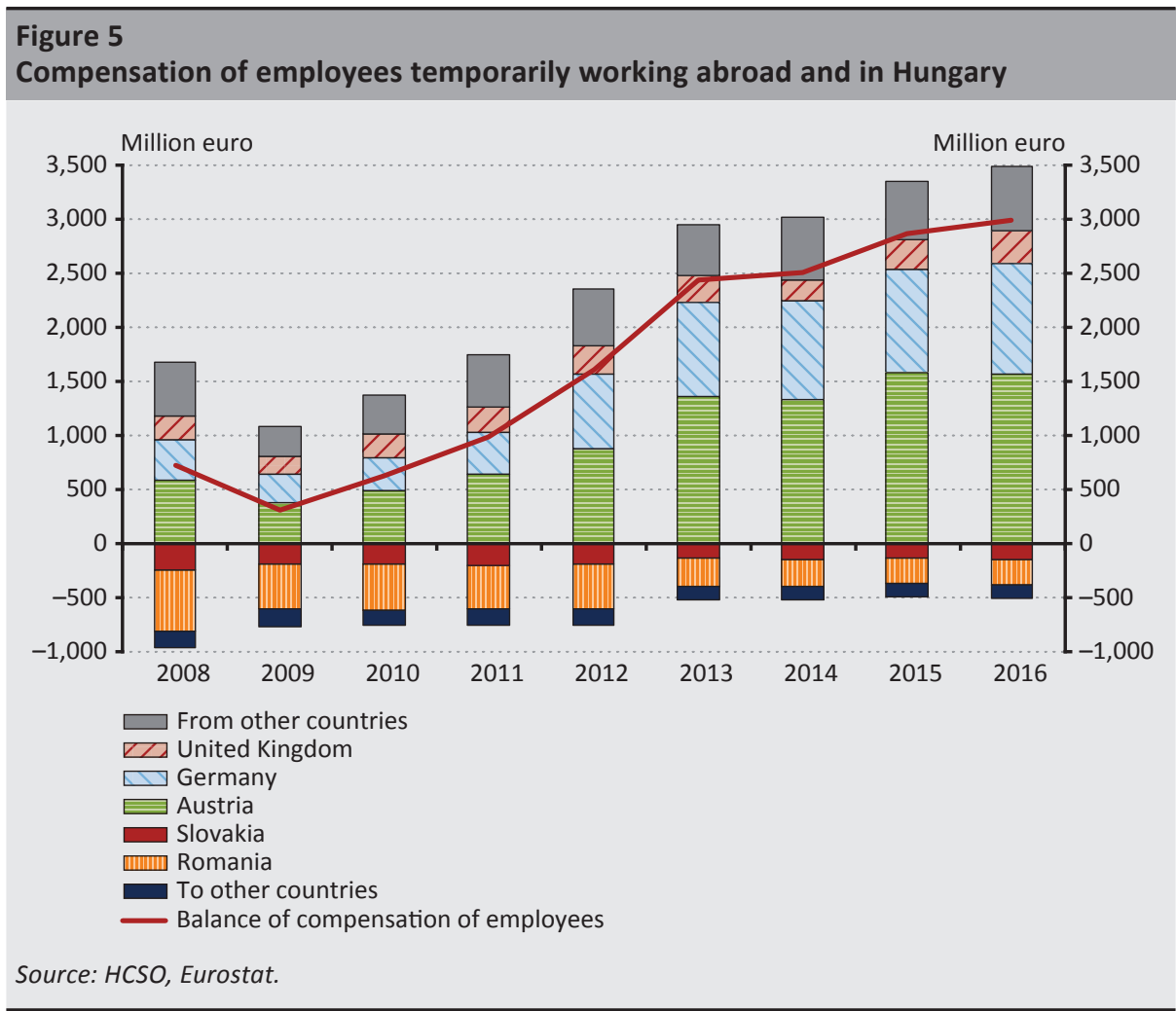

\subsection{Current personal transfers by households working permanently abroad}

Current personal transfers made while working permanently abroad only rose significantly after the crisis, presumably due to the fact that Hungarian workers may have emigrated en masse in the wake of the recession that followed the crisis. The value of current transfers rose significantly and stood at EUR 700 million by 2016, i.e. a far smaller amount than the compensation of employees; however, this amount was fully transferred home. In terms of permanently working abroad, current personal transfers before 2008 were insignificant, falling short of EUR 100 million. Current transfers by Hungarian households working permanently abroad increased significantly following the crisis, presumably in the wake of rising unemployment in Hungary. This may also stem from the fact that the last restrictions affecting Hungarian workers were lifted in 2011, and accordingly remittances from Germany started climbing after this turning point.

From 2012 onwards, the bulk of current transfers by households working permanently abroad came from Germany, followed by the United Kingdom (Figure 6). Current personal transfers grew significantly in 2012 and 2013 mainly in the wake of rising transfers from Germany, as a result of which current personal transfers 
exceeded the amount received from the United Kingdom, the highest up to that point, by 2013 and 2014. Current personal transfers from Germany amounted to around EUR 300 million by 2016 while current transfers from the United Kingdom, which ranked second, amounted to approximately EUR 200 million. An additional EUR 15-20 million is transferred from countries ranking below Germany and the UK (including Sweden, Ireland, Spain, Italy, the Netherlands, Slovakia and Belgium), and fewer transfers are made from other EU countries. In terms of transfers by workers permanently stationed in Hungary, transfers to Germany account for the bulk of their value, while transfers outside the European Union are also significant.

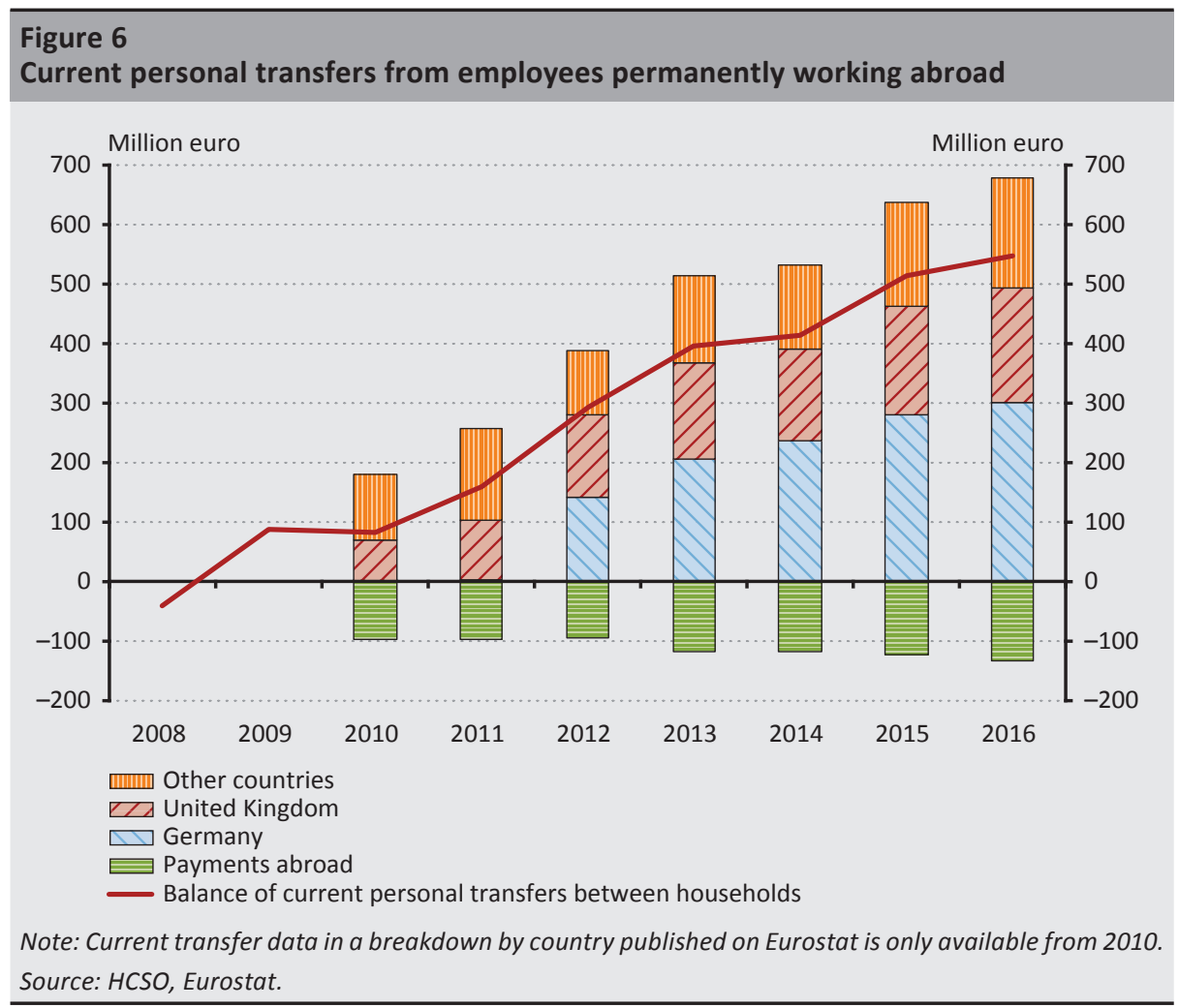

\section{Remittances in an international comparison}

The investigation of compensation of employees and current transfers is not a new topic, but more studies have focused on this matter in the recent past. This stems partly from the increasing compensation of employees and current transfers by workers living abroad, which mostly characterises developing countries. According to the World Bank, compensation of employees and transfers to developing (low and middle income) countries amounted to over USD 420 billion in 2015 and 
can therefore be regarded as a significant source of external funding alongside FDI (Figure 7). In line with this, compensation of employees and transfers may amount to triple the amount of official development funds in certain countries, and may thus exert a market impact on social welfare and economic development. In addition, remittances are a more stable source of funding compared to FDI and portfolio investments, as confirmed by the 2009 trends in the data. While the influx of FDI contracted by nearly one third over a one-year period, remittances only fell by 5 per cent. In terms of the volume of compensation of employees and transfers, the World Bank's data revealed that over 20 per cent originate from the United States (mainly to Mexico, China and India) followed by Saudi Arabia, the United Arab Emirates and the United Kingdom. India, China and the Philippines should be highlighted among the recipients of the largest amounts: these countries absorb nearly 30 per cent of global compensation of employees and transfers.

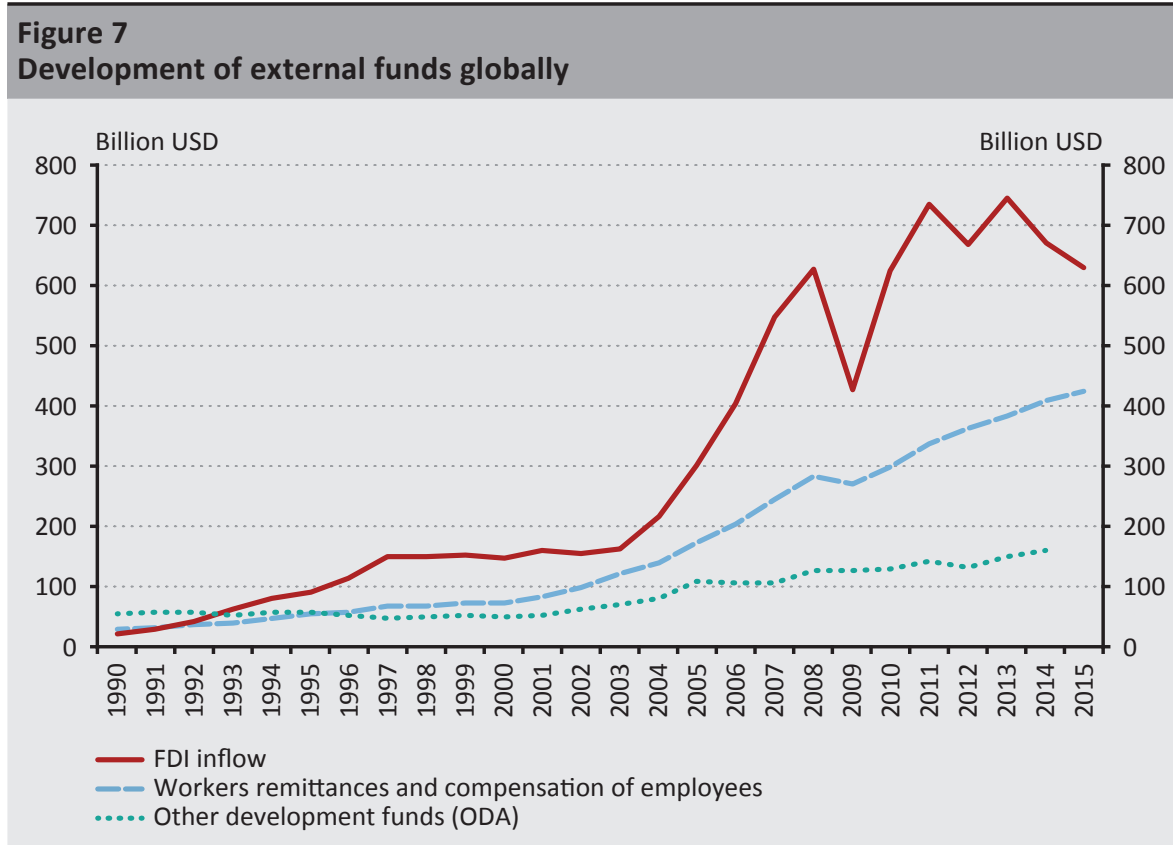

Source: World Bank, http://blogs.worldbank.org/peoplemove/trends-remittances-2016-new-normalslow-growth.

Within the European Union, Hungarian workers abroad boast the highest wages as a percentage of GDP, while their current transfers are not salient (Figure 8). If we compare the countries of the European Union, the compensation of employees working temporarily abroad from Hungary exceed the wages observed in other European Union countries. In this regard, we should keep in mind that as mentioned 
earlier, a portion of this is used to pay taxes and cover the cost of living, and thus the balance of payments surplus is not increased by the total income earned (the precise amount of which is not known). The 0.6 per cent of GDP represented by transfers by households working permanently abroad is not extraordinary in a European comparison. The amount of current transfers is in line with the regional average, which in some instances even exceeds Hungary's figure. It should also be noted that the geographic position of countries may also play a role in shaping revenues from work abroad. As seen earlier, Austria and Germany are the two key countries for Hungary from this perspective, both of which are located nearby. That said, the data for Greece is worth looking at: wages from temporary work abroad are negligible, which may be linked to the fact that Greece does not have any European Union neighbour on land besides Bulgaria.

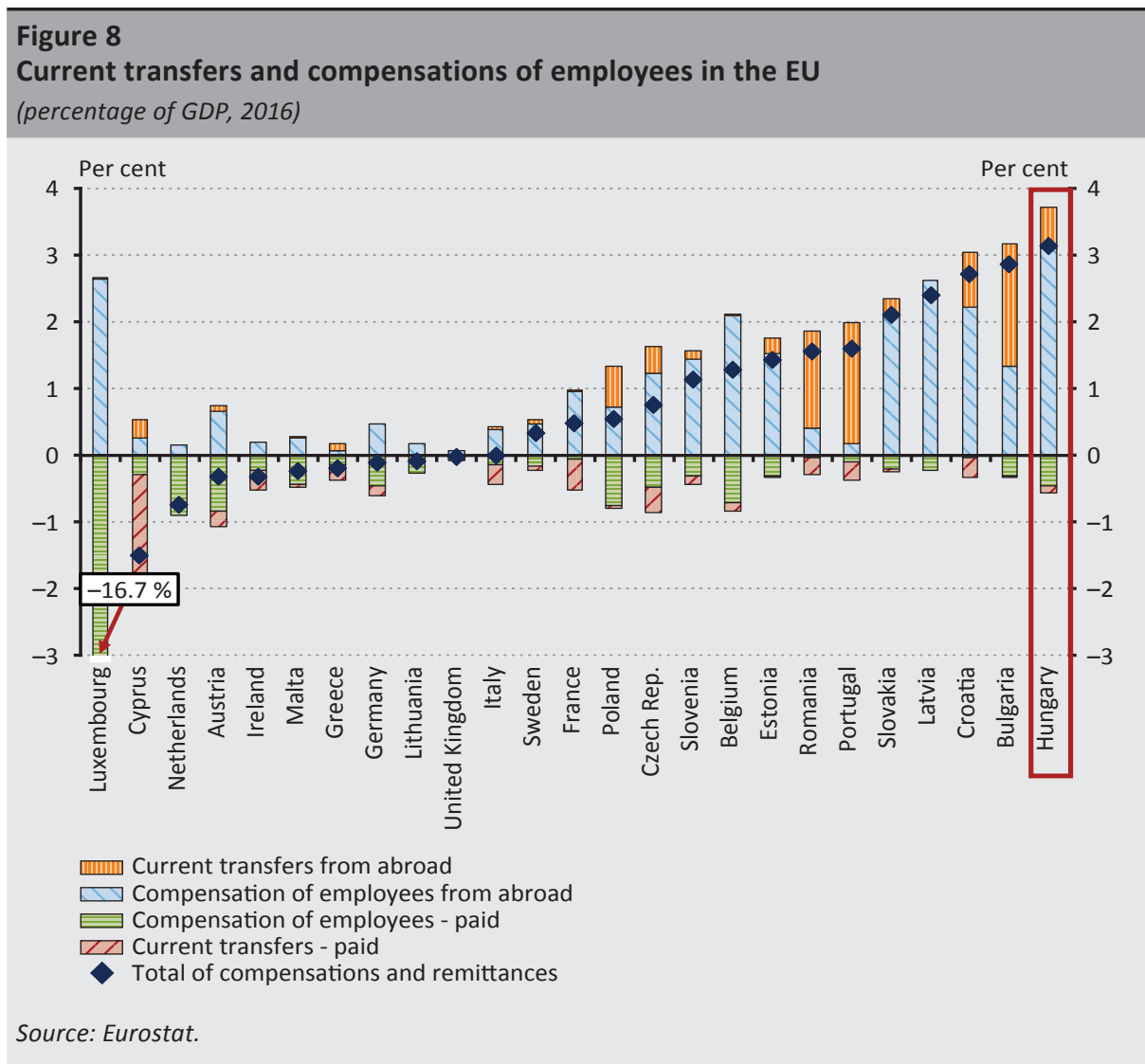

In countries of the European Union, the value of compensation of employees and transfers decreases proportionately as GDP per capita rises, which is linked to wages that increase in line with the level of development (Figure 9). A comparison 
of foreign incomes and transfers with GDP per capita, a measure of economic development, shows that migrant workers transfer far less funds home in more advanced economies, while compensation of employees and transfers are far higher, particularly in the countries that joined the European Union in 2004 or later. Concurrently, countries with higher GDP per capita generally exhibit lower compensation of employees and transfers. This is due to the fact that one of the main motives of seeking work abroad may be to earn higher wages. Thus, countries with higher GDP per capita attract a greater number of foreign workers than the number of its own citizens who emigrate for work.

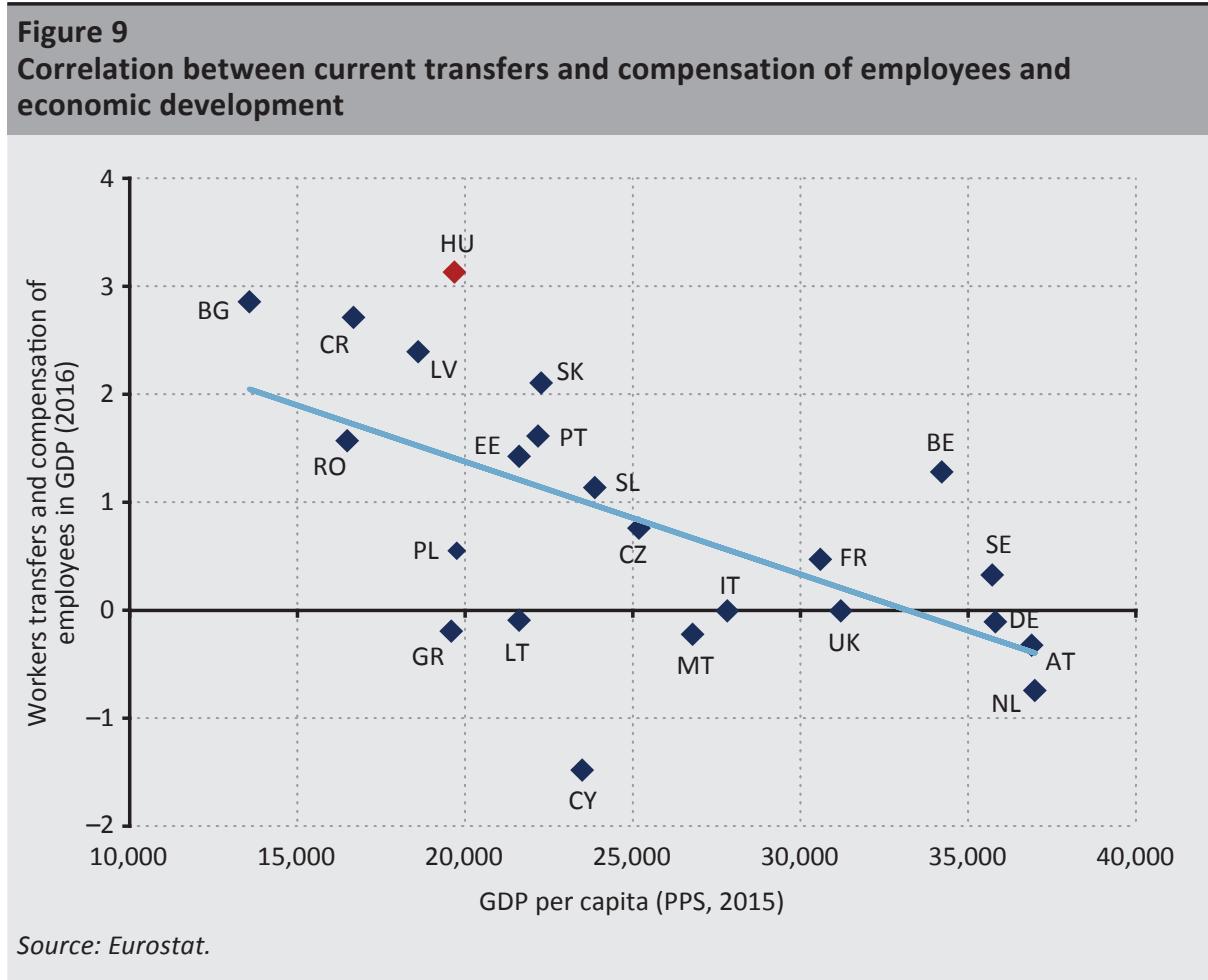

\section{Conclusions}

In summary, a distinction should be made between the amount of compensation of employees and current transfers by households working abroad for the long term and remittances, as the first two items include elements (such as taxes and the cost of living) that are not actually transferred back home. It is necessary to clarify and understand the concepts associated with remittances because they may represent more stable sources of external funding compared to other external sources. 
According to several references in the literature, compensation of employees and transfers and remittances may have a positive impact on economic growth through the stimulation of internal consumption. Meanwhile other authors argue that these transactions may also have negative consequences, for instance through labour market impacts. Compensation of employees and transfers improve the current account balance, which may also have a positive influence on a country' investor sentiment.

A review of Hungarian data reveals that the wages of workers temporarily living abroad far outstripped transfers by households permanently living abroad. Germany and Austria are the leading destinations for Hungarian households seeking temporary work abroad due to the differences in wage levels and their geographic proximity. Germany followed by the United Kingdom are also key countries in terms of long-term work abroad and current transfers. Hungary mainly attracts workers from neighbouring countries (such as Romania and Slovakia), most of whom tend to seek temporary rather than permanent work. European data show that less compensation of employees and transfers are absorbed by more advanced European Union (core) countries, while countries having joined the European Union in 2004 or later are leading sources of migrant labour and major absorbers of remittances.

\section{References}

Adams, R.H., Jr. (1991): The Effects of International Remittances on Poverty, Inequality and Development in Rural Egypt. Research Report No. 96, International Food Policy Research Institute.

Aggarwal, R. - Demirgüc-Kunt, A. - Peria, M.S.M. (2006): Do Workers' Remittances Promote Financial Development? World Bank Policy Research Working Paper No 3957, the WB Group, Washington, D.C.

Ahlburg, D.A. (1996): Remittances and the Income Distribution in Tonga. Population Research and Policy Review, 15(4): 391-400. https://doi.org/10.1007/BF00128431.

Alper, A.M. - Neyapti, B. (2006): Determinants of workers' remittances: Turkish evidence from high frequency data. Eastern European Economics, 44(5): 91-100. https://doi. org/10.2753/EEE0012-8775440504.

Alvarez-Tinajera, S.P. (2010): Angola: A study of the impact of remittances from Portugal and South Africa. Migration Research Series, No 39, IOM, Geneva. 
Barajasa, A. - Chami, R. - Hakura, D. - Montiel, P.J. (2011): Workers' remittances and the equilibrium real exchange rate: Theory and Evidence. Economia, 11: 45-94. https://doi. org/10.1353/eco.2011.0000.

Bodnár, K. - Szabó. L.T. (2014): The Effect of Emigration on the Hungarian Labour Market. MNB-tanulmányok 114.

Bourdet, Y. - Falck, H. (2006): Emigrants' remittances and Dutch disease in Cape Verde. International Economic Journal, 20(3): 267-84. https://doi. org/10.1080/10168730600879323.

Buch, C. - Kuckulenz, A. - Le Manchec, M. (2002): Worker Remittances and Capital Flows. Kiel Working Paper No., 1130, Kiel Institute for World Economics, Kiel.

Buch, C. - Kuckulenz, A. (2004): Worker Remittances and Capital Flows to Developing Countries. Centre for European Economic Research (ZEW) Discussion Paper No. 04-31, ZEW, Mannheim.

Buch, C.M. - Kuckulenz, A. (2010): Worker Remittances and Capital Flows to Developing Countries. International Migration, 48(5): 89-117. https://doi.org/10.1111/j.14682435.2009.00543.x.

Bugamelli, M. - Paternò, F. (2009): Do Workers' Remittances Reduce the Probability of Current Account Reversals? World Development, 37(1): 81-92. https://doi.org/10.1016/j. worlddev.2009.04.002.

Chami, R. - Fullenkamp, C. - Jahjah, S. (2003): Are immigrant Remittance Flows a Source of Capital for Development? IMF Working Papers 03/189, International Monetary Fund, Washington, D.C.

Chami et al. (2008): Macroeconomic Consequences of Remittances. IMF Occasional Paper, 259, International Monetary Fund, Washington.

El-Sakka, M.I.T. - McNabb, R. (1999): The Macroeconomic Determinants of Emigrant Remittances. World Development, 27(8): 1493-1502.

European Parliament (2014): The impacts of remittances on developing countries. http:// www.europarl.europa.eu/RegData/etudes/etudes/join/2014/433786/EXPO-DEVE_ ET(2014)433786_EN.pdf.

De Haas, H. (2007): Remittances, migration and social development. A conceptual review of the literature. UNRISD Programme on Social Policy and Development Paper, No 34, Geneva. 
Giuliano, P. - Ruiz-Arranz, M. (2005): Remittances, Financial Development, and Growth. IMF Working Paper 05/234. International Monetary Fund, Washington.

Giuliano, P. - Ruiz-Arranz, M. (2009): Remittances, financial development and growth. Journal of Development Economics, 90(1): 144-152. https://doi.org/10.1016/j. jdeveco.2008.10.005.

Gupta, S. - Pattillo, C. - Wagh, S. (2009): Impact of Remittances on Poverty and Financial Development in Sub-Saharan Africa. International Monetary Fund.

Glytsos, N.P. (1993): Measuring the Income Effects of Migrant Remittances: A Methodological Approach Applied to Greece. Economic Development and Cultural Change, 42(1): 131-168. https://doi.org/10.1086/452068.

Hassan, G. - Holmes, M. (2015): Do Remittances Facilitate a Sustainable Current Account? The World Economy.

Holmes, M.J. (2006): How sustainable are OECD Current Account Balances in the Long-run? Manchester School, 74(5): 626-643. https://doi.org/10.1111/j.1467-9957.2006.00514.x.

IMF (2005): World Economic Outlook: Globalization and External Imbalances. Washington, D.C.: IMF.

IMF (2009): Balance of payment and international investment position manual 6th edition. IMF. https://www.imf.org/external/pubs/ft/bop/2007/pdf/bpm6.pdf.

IMF (2016): Emigration and Its Economic Impact on Eastern Europe. IMF Staff Discussion Note, July 2016. https://www.imf.org/external/pubs/ft/sdn/2016/sdn1607.pdf.

Kajdi, L. (2015): Hazautalt pénzek - nemzetközi áttekintés és a föbb mérési nehézségek (Worker remittances - international overview and main measurement challenges). Statisztikai Szemle, 93(4): 353-375.

Kapur, D. (2004): Remittances: The New Development Mantra? United Nations Conference on Trade and Development, Geneva.

Lakatos, J. (2015): Külföldön dolgozó magyarok, Magyarországon dolgozó külföldiek (Hungarian emigrant workers, foreigners working in Hungary). Statisztikai Szemle, 93(2): 93-112.

Léon-Ledesma, M. - Piracha, M. (2001): International Migration and the Role of Remittances in Eastern Europe. Studies in Economics, No. 0113, Department of Economics, University of Kent. 
Levitt, P. (1998): Social remittances: Migration driven local-level forums of cultural diffusion. International Migration Review, 32(4): 926-948. https://doi.org/10.2307/2547666.

Lowell, B.L. - de la Garza, R.O. (2002): A new phase in the story of remittances. In: Sending Money Home: Hispanic Remittances and Community Development (R. De la Garza and B. L. Lowell, eds.). Rowmann and Littlefield Publishers, pp. 3-27).

MNB (2014): Magyarország fizetésimérleg- és külfölddel szembeni befektetésipozíció-statisztikái (Hungary's balance of payments and foreign investment position statistics). https:// www.mnb.hu/letoltes/magyarorszagfizetesimerlegeskulfolddelszembenibefektetespoziciostatisztikai2014.pdf, Downloaded: 15 November 2016.

Nayyar, D. (1994): Migration, Remittances and Capital Flows: The Indian Experience. Oxford University Press, Delhi.

OECD (2006): International Migrant Remittances and their Role in Development. International Migration Outlook, Part III. https://www.oecd.org/els/mig/38840502.pdf.

Orozco, M. et al. (2005): Transnational Engagement, Remittances and Their Relationship to Development in Latin America and the Caribbean. Institute for the Study of International Migration, Georgetown University.

Ratha, D. (2003): Workers' remittances: An important and stable source of external development finance. Global Development Finance. World Bank, Washington, D.C.

Ratha, D. - Mohapatra, S. - Silval, A. (2009): Outlook for Remittance Flows 2009-2011: Remittances Expected to Fall by 7-10 Percent in 2009 (Washington, D.C.: Migration and Development Brief, World Bank).

Ratha, D. (2013): The Impact of Remittances on Economic Growth and Poverty Reduction. Migration Policy Institute, Washington, D.C.

Solimano, A. (2003): Workers Remittances to the Andean Region: Mechanism, Costs, and Development Impact. Multilateral Investment Fund-IDB Conference, Remittances and Development, Quito, Ecuador.

Stark, O. - Taylor, J.E. - Yitzhaki, S. (1988): Migration, remittances and inequality: A sensitivity analysis using the extended Gini index. Journal of Development Economics, 28(3): 309-322. https://doi.org/10.1016/0304-3878(88)90002-8.

Stepanyan, V. - Poghosyan, T. - Bibolov, A. (2010): House Price Determinants in Selected Countries of the Former Soviet Union. IMF Working Paper 10/104, International Monetary Fund, Washington. 
Stratan, A. et al. (2013): Development and side effects of remittances in the CIS countries: the case of Republic of Moldova. CARIM-East RR 2013/25, Robert Schuman Centre for Advanced Studies, European University Institute, San Domenico di Fiesola (FI).

Taylor, J.E. (1999): The New Economics of Labour Migration and the Role of Remittances in the Migration Process. 37(1): 63-88. https://doi.org/10.1111/1468-2435.00066.

World Bank (2006): The Development Impact of Workers' Remittances in Latin America. Vol. II: Detailed Findings. The World Bank Group, Washington, D.C.

World Bank (2011): Migration, Remittances, and Development in Africa. World Bank, Washington D.C.

Yasseen, S.H. (2012): The positive and negative impact of remittances on economic growth in MENA countries. The Journal of International Management Studies, 7(1), April. 